\title{
Kesulitan Siswa Kelas XII MIA SMA Negeri Di Kota Palangka Raya Tahun Ajaran 2018/2019 Dalam Memahami Konsep Sel Elektrolisis Yang Ditelusuri Menggunakan Instrumen Two Tier Multiple Choiche
}

\author{
Anastasia Dimas Febyanti ${ }^{*}$, Suandi Sidauruk, Abdul Hadjranul Fatah \\ Program Studi Pendidikan Kimia, FKIP, Universitas Palangka Raya, Indonesia \\ Email: anastasiadimasfebyanti34@gmail.com
}

Diterima: 30 Januari 2020; Disetujui: 14 Februari 2020; Diterbitkan: 29 Februari 2020

\begin{abstract}
ABSTRAK
Sel elektrolisis merupakan ilmu yang mempelajari proses perubahan energi listrik menjadi energi kimia. Sel elektrolisis khususnya sangat berkaitan dengan kehidupan sehari-hari sehingga menjadi salah satu hal penting dalam bidang kimia, namun konsep ini sendiri memiliki tingkat keabstrakan yang cukup tinggi. Keabstrakan ini merupakan salah satu penyebab siswa mengalami kesulitan dalam memahami konsep kimia. Penelitian ini bertujuan untuk mendeskripsikan kesulitan siswa kelas XII MIA SMA Negeri di kota Palangka Raya tahun ajaran 2018/2019 dalam memahami konsep sel elektrolisis yang ditelusuri menggunakan instrumen two tier multiple choice. Subjek penelitian ini adalah siswa kelas XII MIA yang berjumlah 265 siswa. Penelitian ini dilaksanakan pada semester genap tahun ajaran 2018/2019. Data kesulitan siswa dijaring menggunakan Tes Pemahaman Konsep Sel Elektrolisis (TPKSE) dan dilakukan wawancara terhadap siswa yang mengalami kesulitan. Data yang telah diperoleh kemudian dianalisis secara deskriptif. Hasil Penelitian menunjukkan bahwa presentase jumlah siswa yang mengalami kesulitan dalam memahami konsep elektrolisis sebesar 68,39\%.
\end{abstract}

Kata Kunci : elektrolisis, kesulitan, two tier multiple choice

\section{PENDAHULUAN}

Ilmu kimia adalah ilmu yang mempelajari tentang segala sesuatu yang berhubungan dengan materi yang meliputi hakikat, susunan, sifat-sifat, perubahan materi, serta energi yang menyertai perubahan materi (Chang, 2010). Banyak siswa yang kesulitan dalam mempelajari ilmu kima tersebut. Hal ini disebabkan banyaknya konsep yang bersifat abstrak yang harus diterima oleh siswa. Keabstrakan konsep-konsep kimia harus melalui pendefinisian, sementara dalam definisi tersebut biasanya selalu mengandung istilah-istilah lain yang membutuhkan pemahaman ekstra dari siswa (Sidauruk, 1995).

Menurut Suwarto (2013) kesulitan belajar adalah kegagalan dalam mencapai tujuan belajar, ditandai dengan prestasi belajar yang rendah (nilai yang diperoleh kurang dari tujuh puluh lima). Siswa yang mempunyai kesulitan belajar 
adalah siswa yang tidak dapat mencapai tingkat penguasaan yang diperlukan sebagai prasyarat untuk belajar ditingkat berikutnya. Penyebab kesulitan dalam mempelajari ilmu kimia salah satunya adalah kebanyakan konsep-konsep atau materi kimia bersifat abstrak seperti atom, molekul, ion sehingga siswa sulit membayangkan keberadaan materi tersebut tanpa mengalami secara langsung

Salah satu pokok bahasan dalam mata pelajaran kimia kelas XII SMA adalah elektrokimia. Materi ini merupakan salah satu materi yang penting dalam bidang kimia. Elektrokimia adalah salah satu cabang ilmu kimia yang menyelidiki hubungan antara energi listrik dan energi kimia, elektrokimia dibedakan menjadi dua, yaitu sel volta yang mempelajari proses energi kimia menjadi energi listrik sedangkan sel elektrolisis merupakan kebalikan dari sel volta mempelajari proses energi listrik menjadi energi kimia. Sel elektrolisis khususnya sangat berkaitan dengan kehidupan sehari-hari sehingga menjadi hal penting dalam bidang kimia seperti contohnya sendok dan garpu yang dilapisi perak dengan teknik elektroplating merupakan salah satu penerapan pada sel elektrolisis, namun konsep ini sendiri bersifat abstrak karena siswa tidak dapat melihat secara langsung bagaimana proses energi listrik menjadi energi kimia tersebut sehingga sebagian besar siswa sering melakukan kesalahan dalam menjawab soal mengenai materi ini (Suryanto, 2018).

Hasil penelitian Tresnasih (2013) menunjukkan bahwa sebagaian besar mahasiswa semester VI di salah satu LPTK di Bandung masih mengalami miskonsepsi dalam memahami indikator pergerakan elektron, ditunjukkan dari hasil wawancara peneliti, mahasiswa menganggap bahwa elektron bergerak dari kation menuju anion. Diindikasikan mahasiswa mengkaitkan pergerakan elektron ini dengan konsep serah terima elektron pada materi redoks. Sehingga dapat disimpulkan bahwa miskonsepsi yang terjadi disebabkan oleh kesalahan berpikir yang diakibatkan karena konsep prasyarat yang tidak terpenuhi. Indikator lain yang menyebabkan miskonsepsi yaitu pada aspek kuantitatif elektrolisis, yaitu menghitung massa zat hasil elektrolisis dengan waktu yang berbeda.

Hasil-hasil penelitian tersebut diperkuat dengan hasil observasi yang telah dilakukan peneliti. Data hasil observasi dipaparkan sebagai berikut:

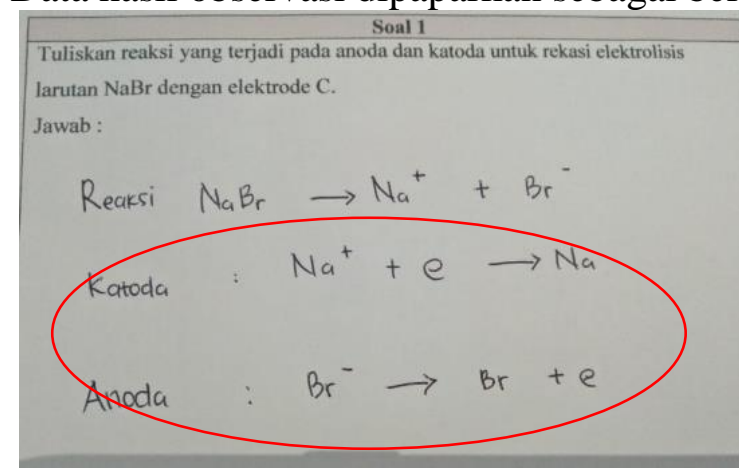

Siswa mengalami kesulitan dalam menentukan reaksi yang terjadi pada katoda dan anoda dalam sel elektrolisis, siswa beranggapan bahwa dalam larutan Natrium Bromida yang mengalami reduksi adalah ion Natrium karena merupakan ion positif pada reaksi tersebut, konsep yang benar adalah apabila kation berupa ion aktif yakni ion logam pada golongan IA, IIA dan sebagian golongan IIIA seperti Natrium maka yang tereduksi adalah air karena kation tersebut tidak dapat diendapkan pada katoda. 
Hasil observasi menunjukkan bahwa banyak konsep dalam pokok bahasan sel elektrolisis yang membuat siswa mengalami kesulitan belajar, dalam hal inilah pendidik harus mengetahui letak konsep apa saja yang membuat siswa mengalami kesulitan agar pendidik dapat melakukan evaluasi materi ataupun gaya belajar yang sesuai dengan tingkat pemahaman kesulitan materi yang dihadapi siswa. Kesulitan siswa dapat diketahui dengan mendiagnosis kemampuan siswa dalam suatu konsep yang ingin dicapai. Mendiagnosis kesulitan siswa dapat dijaring menggunakan tes diagnostik.

Salah satu bentuk tes diagnostik adalah two tier multiple choice. Pada tes ini terdiri atas soal pilihan ganda dua tingkat. Pada tingkat pertama terdiri dari pertanyaan tentang konsep yang diujikan, Sedangkan pada tingkat kedua berisi alasan jawaban pada tingkat pertama. Instrumen two tier multiple choice membuat guru dapat mengetahui konsep yang sering terjadi yakni miskonsepsi pada siswa ataupun konsep yang belum dipahami oleh siswa, karena terjadinya miskonsepsi dan ketidakpahaman siswa dapat mengakibatkan kesulitan pada siswa dalam memahami konsep yang diujikan.

Uraian di atas menjadi latar belakang untuk melakukan penelitian skripsi dengan judul "Kesulitan Siswa Kelas XII MIA SMA Negeri Di Kota Palangka Raya Tahun Ajaran 2018/2019 Dalam Memahami Konsep Sel Elektrolisis Yang Ditelusuri Menggunakan Instrumen Two Tier Multiple Choice"

Penelitian ini bertujuan untuk mendeskripsikan kesulitan siswa kelas XII MIA SMA Negeri di Kota Palangka Raya tahun ajaran 2018/2019 dalam memahami konsep sel elektrolisis. Penelitian serupa juga telah dilakukan oleh Hayati (2018), Lumban Tobing (2019) dan Sibarani (2019) pada konsep yang berbeda.

\section{METODOLOGI}

Penelitian ini dilaksanakan pada semester genap tahun ajaran 2018/2019. Pengambilan data pada penelitian ini melibatkan tiga SMA Negeri di Kota Palangka Raya yakni SMA Negeri 1 Palangka Raya, SMA Negeri 2 Palangka Raya, dan SMA Negeri 3 Palangka Raya. Subjek dalam penelitian ini adalah siswa kelas XII MIA yang berjumlah 265 siswa.

Asumsi dalam penelitian ini adalah siswa telah mempelajari materi elektrolisis di kelas XII semester ganjil berdasarkan kurikulum 2013.

Instrumen yang digunakan pada penelitian ini berupa tes tertulis dan pedoman wawancara. Tes tertulis yang digunakan sebagai instrumen dalam penelitian ini dinamakan Tes Pemahaman Konsep Sel Elektrolisis (TPKSE) dengan 13 butir soal Pilihan ganda dua tingkat (two tier multiple choice) yang dibuat berdasarkan pengembangan indikator yang terdapat pada silabus mata pelajaran kimia kurikulum 2013. Rincian kompetensi dasar dan indikator yang sesuai dengan silabus mata pelajaran kimia kurikulum 2013 revisi 2018 dapat dilihat pada Tabel 1 .

Tabel 1 : Indikator TPKSE Berdasarkan Kurikulum 2013

\begin{tabular}{|c|c|c|}
\hline \multirow{2}{*}{$\begin{array}{l}\text { Kompetensi Dasar } \\
\text { 3.6 } \begin{array}{l}\text { Menerapkan } \\
\text { stoikiometri reaksi }\end{array}\end{array}$} & \multicolumn{2}{|r|}{ Indikator TPKSE } \\
\hline & 3.7 .1 & $\begin{array}{l}\text { Menentukan reaksi sel elektrolisis } \\
\text { lelehan/leburan. }\end{array}$ \\
\hline redoks dan Hukum & 3.7 .2 & Menentukan reaksi sel elektrolisis larutan pada \\
\hline
\end{tabular}




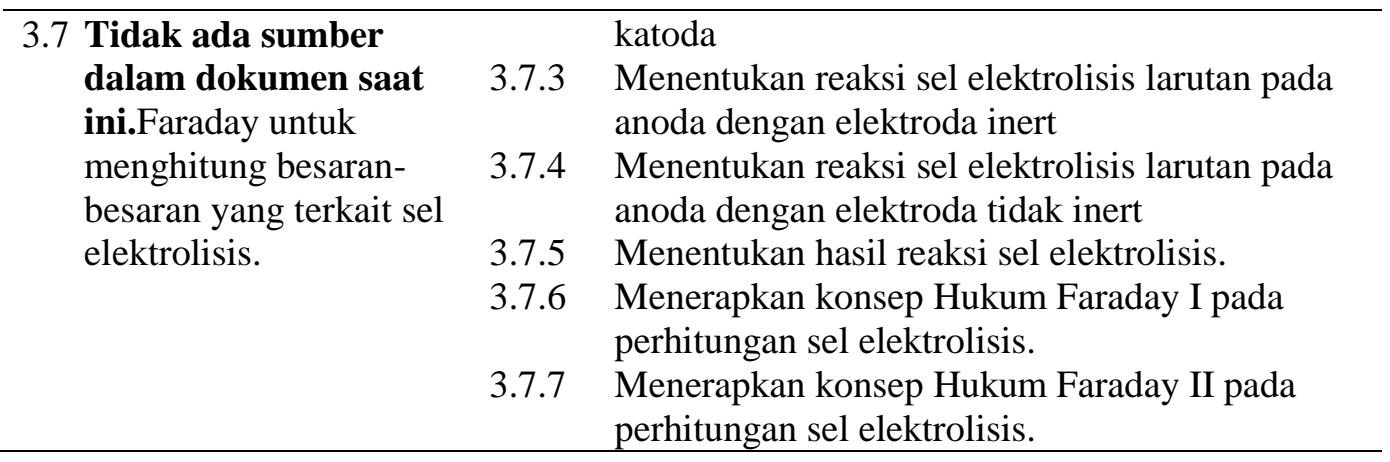

Data penelitian ini berupa data kesulitan siswa dalam pelajaran kimia pada konsep sel elektrolisis. Data penelitian ini dikumpulkan menggunakan tes tertulis yaitu dengan soal TPKSE diberikan kepada siswa yang menjadi subjek penelitian. Kisi-kisi instrumen atau materi diasosiasikan kepada siswa satu hari sebelum penelitian. Lembar TPKSE diujikan dengan alokasi waktu $2 \times 45$ menit. Soal TPKSE dikerjakan siswa didalam ruangan kelas pada jam pelajaran. Hasil Jawaban siswa dikumpulkan.

Wawancara dilakukan sebagai crosscheck (memeriksa kembali) atas jawaban yang telah dikumpulkan guna menggali informasi lebih dalam mengenai konsep elektrolisis, dengan diberikan beberapa pertanyaan kepada siswa yang berhubungan dengan pola jawaban siswa. Wawancara dilakukan dengan bantuan alat perekam suara. Tujuannya, agar data yang diperoleh dapat disimpan secara langsung dan juga membantu peneliti dalam mendeskripsikan kesulitan yang dialami siswa.

Teknik analisis data yang digunakan dalam penelitian ini adalah identifikasi distribusi pasangan jawaban-alasan pada tiap konsep sel elektrolisis, kemudian rerata presentase jumlah siswa yang mengalami kesulitan (jumlah siswa yang menjawab dengan kode BS, SB, SS dan TM) dihitung dengan persamaan berikut:

$$
\% K=\frac{\sum \text { siswa yang menjawab salah }}{\sum \text { seluruh siswa }} \times 100 \%
$$

Hasil perhitungan presentase kesulitan ini kemudian dikelompokkan sesuai dengan kriteria kesulitan sebagai berikut (Siwi, 2013) :

Tabel 2. Kriteria Kesulitan

\begin{tabular}{cc}
\hline Kriteria & Presentase \\
\hline Tinggi & $61 \%-100 \%$ \\
Sedang & $31 \%-60 \%$ \\
Rendah & $0 \%-30 \%$ \\
\hline
\end{tabular}

Presentase jumlah siswa yang mengalami kesulitan dikelompokkan berdasarkan asal sekolah. Kesalahan dominan siswa ditentukan berdasarkan pola distribusi pasangan jawaban-alasan. Perwakilan siswa dengan jawaban salah dominan diwawancara, dan hasil wawancara siswa dideskripsikan untuk menjelaskan kesulitan yang dialami oleh siswa dalam menyelesaikan soal. 


\section{HASIL PENELITIAN DAN PEMBAHASAN}

Pengambilan data pada penelitian ini dilaksanakan pada tiga sekolah di Kota Palangka Raya dengan subjek penelitian siswa kelas XII MIA, yakni sebagai berikut:

1. SMA Negeri 2 Palangka Raya, dengan total subjek 114 siswa. Pengambilan data dilakukan pada tanggal 11-12 Februari 2019 dan 4-5 Maret 2019

2. SMA Negeri 3 Palangka Raya, dengan total subjek 75 siswa. Pengambilan data dilakukan pada tanggal 13-14 Februari 2019 dan 6-7 Maret 2019

3. SMA Negeri 4 Palangka Raya, dengan total subjek 76 siswa. Pengambilan data dilakukan pada tanggal 21 Februari 2019 dan 14 Maret 2019

Alokasi waktu penelitian pada ketiga sekolah tersebut dilaksanakan dengan waktu yang sama yakni $2 \times 45$ menit pada semester genap tahun 2018/2019. Hasil jawaban yang telah dikerjakan kemudian dikumpulkan Ditentukan dominan jawaban salah siswa, kemudian perwakilan siswa tersebut diwawancara. Kesulitan yang didapatkan kemudian dideskripsikan.

Berdasarkan jawaban siswa diperoleh rerata jumlah siswa yang mengalami kesulitan yakni siswa yang menjawab salah pada tiap konsep sel elektrolisis yang disajikan pada Tabel 3 berikut:

Tabel 3. Presentase Kesulitan Siswa per konsep Elektrolisis

\begin{tabular}{lccc}
\hline \multicolumn{1}{c}{ Konsep } & $\begin{array}{c}\text { Paham } \\
\text { Konsep }\end{array}$ & Kesulitan & $\begin{array}{c}\text { Kriteria } \\
\text { Kesulitan }\end{array}$ \\
\hline Reaksi Elektrolisis Lelehan/Leburan & 38,9 & 61,1 & Tinggi \\
Reaksi Elektrolisis Larutan di Katoda & 31,9 & 68,1 & Tinggi \\
Reaksi Elektrolisis Larutan di Anoda dengan & 31,6 & 68,4 & Tinggi \\
Elektroda Inert & & & \\
Reaksi Elektrolisis Larutan di Anoda dengan & 31,7 & 68,3 & Tinggi \\
Elektroda Tidak Inert & 29,8 & 70,1 & Tinggi \\
Hasil reaksi total sel elektrolisis & 29,1 & 71 & Tinggi \\
Hukum Faraday I & 28,3 & 71,7 & Tinggi \\
Hukum Faraday II & 221,3 & 478,7 & \\
Total & 31,61 & 68,39 & Tinggi \\
Rata-Rata & & & \\
\hline
\end{tabular}

Tabel 3 menunjukkan secara keseluruhan pada materi elektrolisis meliputi tujuh konsep yang diujikan, presentase rata-rata kesulitan yang dialami siswa dalam memahami konsep sel elektrolisis sebesar 68,39\% dengan kriteria kesulitan tinggi. Hal ini menandakan masih banyak siswa yang mengalami kesulitan dalam memahami konsep sel elektrolisis tersebut yang disebabkan karena miskonsepsi dan ketidakpahaman siswa pada materi sel elektrolisis. Grafik rata-rata jumlah siswa yang mengalami kesulitan ditunjukkan pada Gambar 1 berikut: 


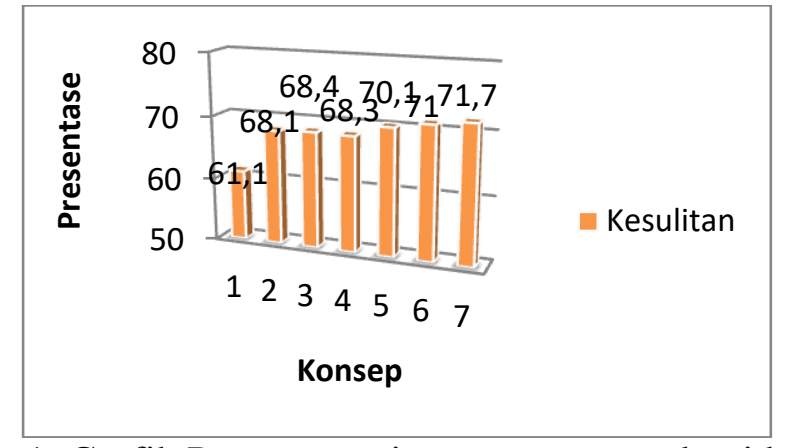

Gambar 1: Grafik Presentase siswa yang mengalami kesulitan

Deskripsi hasil penelitian yang dibahas pada bagian ini meliputi deskripsi presentase kesulitan siswa yang mengacu pada tujuh indikator dalam penelitian ini. Berikut adalah deskripsi kesulitan pada masing-masing konsep:

\section{Kesulitan Menentukan Reaksi Sel Elektrolisis Lelehan/Leburan}

Kesulitan dalam menentukan reaksi sel elektrolisis lelehan/leburan ditelusuri dengan menggunakan instrumen TPKSE yang terdiri dari satu butir soal, yakni terdapat pada soal nomor 1. Melalui tes yang telah dilakukan diperoleh rerata jumlah siswa yang mengalami kesulitan sebesar $61.1 \%$ dengan kategori jawaban SS, BS, SB dan TM. Pola distribusi pasangan jawaban-alasan siswa pada butir soal nomor 1 disajikan pada Tabel 4.

Tabel 4. Pola Distribusi Pasangan Jawaban-Alasan Siswa

\begin{tabular}{|c|c|c|c|}
\hline No & $\begin{array}{c}\text { Pilihan } \\
\text { Jawaban }\end{array}$ & $\begin{array}{c}\text { Jumlah } \\
\text { Siswa }\end{array}$ & Pilihan Alasan \\
\hline \multirow[t]{5}{*}{1} & $\mathrm{~A}$ & 2 & $\begin{array}{l}\text { 1. Ion } \mathrm{Mg}^{2+} \text { merupakan ion aktif yang tidak dapat } \\
\text { diendapkan pada katoda, maka spesi yang tereduksi } \\
\text { adalah air }\end{array}$ \\
\hline & $\mathrm{B}^{*}$ & $103^{*}$ & $\begin{array}{l}\text { 2. Pada elektrolisis lelehan } \mathrm{MgCl}_{2} \text { tidak mengandung air } \\
\text { sehingga yang tereduksi maupun teroksidasi adalah } \\
\text { kation dan anion pada lelehan tersebut* }\end{array}$ \\
\hline & $\mathrm{C}$ & 33 & $\begin{array}{l}\text { 2. Pada elektrolisis lelehan } \mathrm{MgCl}_{2} \text { tidak mengandung air } \\
\text { sehingga yang tereduksi maupun teroksidasi adalah } \\
\text { kation dan anion pada lelehan tersebut* }\end{array}$ \\
\hline & D & 49 & $\begin{array}{l}\text { 1. Ion } \mathrm{Mg}^{2+} \text { merupakan ion aktif yang tidak dapat } \\
\text { diendapkan pada katoda, maka spesi yang tereduksi } \\
\text { adalah air }\end{array}$ \\
\hline & $\mathrm{E}$ & 2 & $\begin{array}{l}\text { 1. Ion } \mathrm{Mg}^{2+} \text { merupakan ion aktif yang tidak dapat } \\
\text { diendapkan pada katoda, maka spesi yang tereduksi } \\
\text { adalah air }\end{array}$ \\
\hline
\end{tabular}

Pada butir soal nomor 1 diberikan data beberapa reaksi, siswa diarahkan menentukan reaksi reduksi yang terjadi pada katoda dan reaksi oksidasi di anoda pada lelehan. Jawaban yang benar adalah: Reaksi reduksi di katoda adalah ion $\mathrm{Mg}^{2+}$ sedangkan spesi yang teroksidasi adalah ion $\mathrm{Cl}^{-}$(Opsi B). Elektrolisis lelehan $\mathrm{MgCl}_{2}$ tidak mengandung air sehingga yang tereduksi maupun teroksidasi adalah kation dan anion pada lelehan tersebut (Opsi 2). Siswa yang menjawab benar 
Pada butir soal nomor 1 diberikan data beberapa reaksi, siswa diarahkan menentukan reaksi reduksi yang terjadi pada katoda dan reaksi oksidasi di anoda pada lelehan. Jawaban yang benar adalah:

Reaksi reduksi di katoda :

Reaksi oksidasi di anoda:

$$
\mathrm{Mg}^{2+}(l)+2 \mathrm{e}^{-} \rightarrow \mathrm{Mg}_{(s)}
$$

$$
2 \mathrm{Cl}_{(a q)} \rightarrow \mathrm{Cl}_{2(g)}+2 \mathrm{e}^{-}(\text {Opsi B) }
$$

Elektrolisis lelehan $\mathrm{MgCl}_{2}$ tidak mengandung air sehingga yang tereduksi maupun teroksidasi adalah kation dan anion pada lelehan tersebut (Opsi 2). Siswa yang menjawab benar pada soal tersebut sebanyak 103 orang, artinya 162 siswa yang menjawab salah. Jawaban salah dominan pada soal tersebut yakni siswa menjawab pasangan reaksi yang terbentuk di katoda dan anoda berturut-turut adalah reaksi reduksi air di katoda dan reaksi oksidasi ion $\mathrm{Cl}^{-}$di anoda (Opsi D) dengan alasan Ion $\mathrm{Mg}^{2+}$ merupakan ion aktif yang tidak dapat diendapkan pada katoda, maka spesi yang tereduksi adalah air (Opsi 1). Jawaban siswa tersebut ditunjukkan pada Gambar 2 berikut:

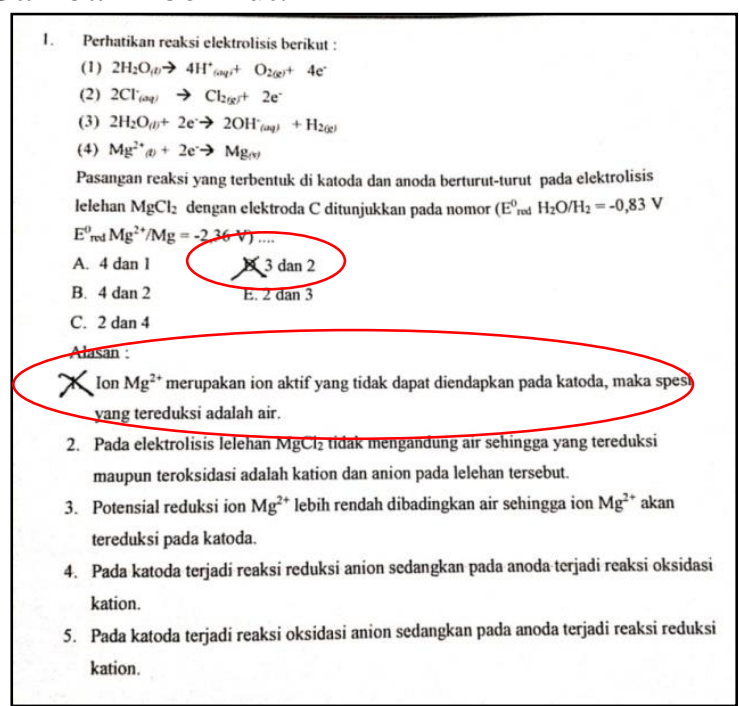

Gambar 2. Jawaban Siswa

Jawaban salah siswa seperti yang disajikan pada Gambar 2 dapat diartikan jika suatu lelehan mengadung ion aktif atau spesi yang memiliki potensial reduksi di bawah potensial reduksi air, maka spesi yang akan tereduksi adalah air. Hasil wawancara menunjukkan bahwa kesulitan yang dialami siswa adalah menganggap reaksi reduksi dan oksidasi pada lelehan bergantung dengan jenis kation dan anion sama seperti dengan reaksi elektrolisis larutan, karena baik senyawa lelehan maupun larutan mengandung pelarut air.

\section{Kesulitan Menentukan Reaksi Sel Elektrolisis Larutan Di Katoda}

Kesulitan dalam menentukan reaksi sel elektrolisis pada larutan yang terjadi di katoda ditelusuri dengan menggunakan instrumen TPKSE yang terdiri dari tiga butir soal, yakni terdapat pada soal nomor 2, 3, dan 4. Melalui tes yang telah dilakukan diperoleh rerata jumlah siswa yang mengalami kesulitan sebesar $68.1 \%$ dengan kategori jawaban SS, BS, SB dan TM. Pola distribusi jawaban-alasan siswa pada ketiga butir soal tersebut disajikan pada Tabel 5. 
Tabel 5. Pola Distribusi Pasangan Jawaban-Alasan Siswa

\begin{tabular}{|c|c|c|c|}
\hline No & Pilihan Jawaban & $\begin{array}{l}\text { Jumlah } \\
\text { Siswa }\end{array}$ & Pilihan Alasan \\
\hline \multirow[t]{3}{*}{2} & A & 25 & $\begin{array}{l}\text { 2. Potensial reduksi ion } \mathrm{K}^{+} \text {lebih kecil dari pada air } \\
\text { maka yang akan tereduksi adalah ion } \mathrm{K}^{+}\end{array}$ \\
\hline & B & 29 & $\begin{array}{l}\text { 1. Potensial reduksi ion } \mathrm{K}^{+} \text {lebih kecil dari pada air } \\
\text { maka yang akan tereduksi adalah air* }\end{array}$ \\
\hline & $\mathrm{E}^{*}$ & $88^{*}$ & $\begin{array}{l}\text { 1. Potensial reduksi ion } \mathrm{K}^{+} \text {lebih kecil dari pada air } \\
\text { maka yang akan tereduksi adalah air* }\end{array}$ \\
\hline
\end{tabular}

Pada butir soal nomor 2 disajikan dalam bentuk gambar rangkaian sel elektrolisis larutan, siswa diminta menentukan reaksi reduksi yang terjadi pada katoda dengan kation yang berbeda yakni berupaion aktif dan ion yang dapat diendapkan pada katoda. Jawaban yang benar reaksi yang terjadi di katoda pada larutan KI adalah $2 \mathrm{H}_{2} \mathrm{O}_{(l)}+2 \mathrm{e}^{-} \rightarrow 2 \mathrm{OH}_{(a q)}^{-}+\mathrm{H}_{2(g)}(\mathrm{Opsi} \mathrm{E})$ dengan alasan potensial reduksi ion $\mathrm{K}^{+}$lebih kecil dari pada air maka yang akan tereduksi adalah air (Opsi 1). Siswa yang menjawab benar pada soal tersebut sebanyak 88 siswa, artinya 177 siswa yang menjawab salah. Jawaban salah dominan pada soal tersebut yakni siswa menjawab reaksi reduksi yang terjadi pada larutan KI adalah $2 \mathrm{H}_{2} \mathrm{O}_{(l)} \rightarrow$ $4 \mathrm{H}_{(a q)}^{+} \mathrm{O}_{2(g)}+4 \mathrm{e}^{-}(\mathrm{Opsi} \mathrm{B})$ dengan alasan yang tepat yakni karena air memiliki potensial reduksi yang lebih besar atau lebih positif daripada kation $\mathrm{K}^{+}($Opsi 1$)$. Jawaban siswa tersebut ditunjukkan pada Gambar 3 berikut.

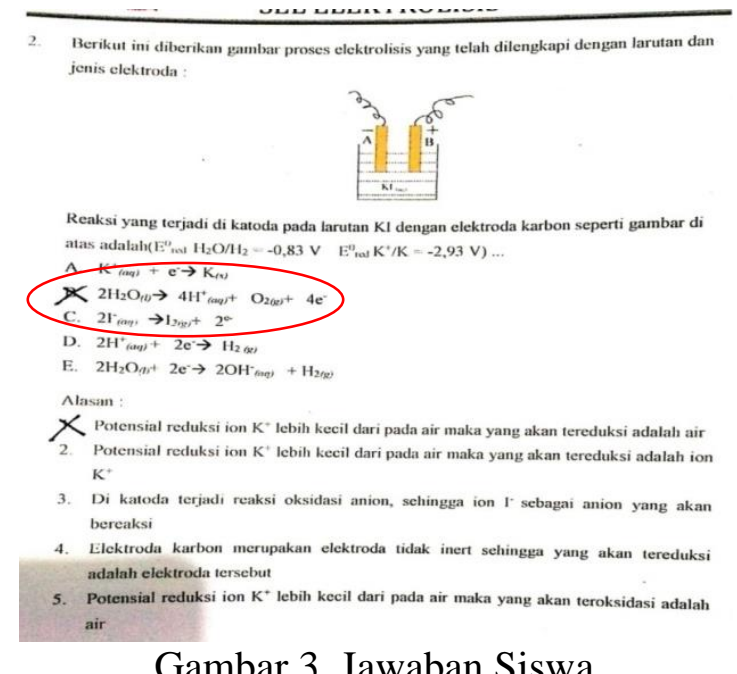

Gambar 3. Jawaban Siswa

Jawaban salah siswa seperti yang ditunjukkan pada gambar 3 tersebut dapat diartikan bahwa siswa belum memahami secara benar untuk menentukan reaksi reduksi, siswa menganggap bahwa reaksi yang dipilihnya tersebut merupakan reaksi setengah reduksi air. Berikut adalah kutipan wawancara yang dilakukan, untuk memperjelas jawaban siswa tersebut :

Hasil wawancara menunjukkan bahwa kesulitan yang dialami siswa yakni dalam menentukan bilangan oksidasi pada setengah reaksi reduksi air sehingga jawaban yang dipilih siswa tersebut bukan reaksi reduksi air melainkan reaksi oksidasi pada air yang menyebabkan siswa kesulitan dalam menentukan reaksi sel elektrolisis pada larutan yang terjadi di katoda. 


\section{Kesulitan Menentukan Reaksi Sel Elektrolisis Larutan Di Anoda dengan Elektroda Inert}

Kesulitan dalam menentukan reaksi sel elektrolisis pada larutan yang terjadi di katoda ditelusuri dengan menggunakan instrumen TPKSE yang terdiri dari tiga butir soal, yakni pada soal nomor 5, 6 dan 7. Melalui tes yang telah dilakukan diperoleh rerata jumlah siswa yang mengalami kesulitan sebesar 68,4\% dengan kategori jawaban SS, BS, SB dan TM. Pola distribusi pasangan jawabanalasan ditunjukkan pada tabel berikut:

Tabel 6. Pola Distribusi Pasangan Jawaban-Alasan Siswa Pada Butir Soal

\begin{tabular}{|c|c|c|c|}
\hline No & $\begin{array}{c}\text { Pilihan } \\
\text { Jawaban }\end{array}$ & $\begin{array}{c}\text { Jumlah } \\
\text { Siswa }\end{array}$ & Pilihan Alasan \\
\hline \multirow[t]{4}{*}{5} & B & 39 & $\begin{array}{l}\text { 3. Bilangan oksidasi } \mathrm{N} \text { pada } \mathrm{NO}_{3}^{-} \text {pada larutan telah mencapai keadaan } \\
\text { maksimum sehingga tidak dapat teroksidasi.* }\end{array}$ \\
\hline & $\mathrm{C}^{*}$ & 31 & $\begin{array}{l}\text { 2. Larutan } \mathrm{KNO}_{3} \text { mengandung ion aktif maka yang tereduksi pada } \\
\text { katoda adalah air. }\end{array}$ \\
\hline & & $83^{*}$ & $\begin{array}{l}\text { 3. Bilangan oksidasi } \mathrm{N} \text { pada } \mathrm{NO}_{3}^{-} \text {pada larutan telah mencapai keadaan } \\
\text { maksimum sehingga tidak dapat teroksidasi.* }\end{array}$ \\
\hline & $\mathrm{E}$ & 41 & $\begin{array}{l}\text { 5. Larutan } \mathrm{KNO}_{3} \text { dengan elektrode inert yang teroksidasi pada anoda } \\
\text { adalah ion } \mathrm{K}^{+} \text {. }\end{array}$ \\
\hline
\end{tabular}

Butir soal nomor 5 bertujuan untuk menelusuri kesulitan siswa dalam memahami konsep reaksi elektrolisis pada larutan yang terjadi di anoda jika anion berupa sisa asam oksi. Jawaban yang benar untuk butir soal nomor 5, spesi yang akan bereaksi pada kutub positif larutan $\mathrm{H}_{2} \mathrm{O}$ (Opsi C) dengan alasan bilangan oksidasi $\mathrm{N}$ pada $\mathrm{NO}_{3}{ }^{-}$pada larutan telah mencapai keadaan maksimum sehingga tidak dapat teroksidasi (Opsi 3). Siswa yang menjawab benar pada butir soal nomor 5 sebanyak 83 siswa, yang artinya ada 182 siswa menjawab salah pada soal ini.

Jawaban salah dominan dari butir soal nomor 5 yakni menjawab reaksi bereaksi pada kutub positif larutan $\mathrm{KNO}_{3}$ adalah ion $\mathrm{NO}^{3-}$ (Opsi E) dengan alasan bahwa bilangan oksidasi $\mathrm{N}$ pada $\mathrm{NO}_{3}{ }^{-}$pada larutan telah mencapai keadaan maksimum sehingga dapat teroksidasi (Opsi 5). Jawaban tersebut ditunjukkan pada Gambar berikut ini.

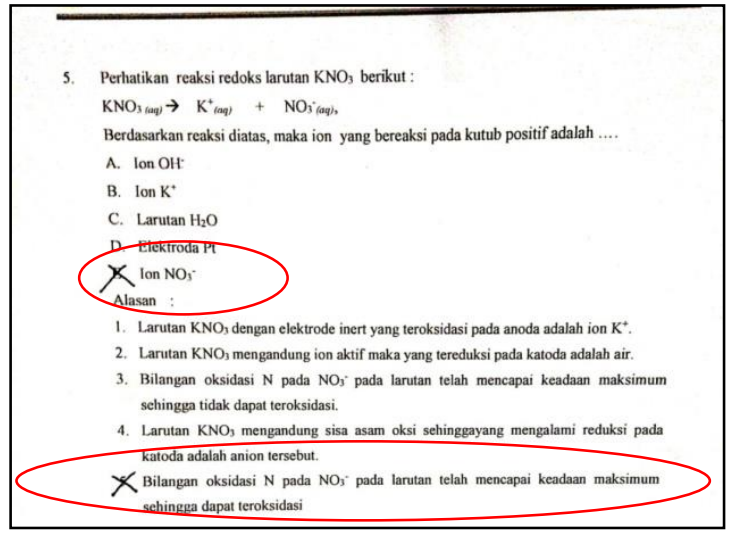

Gambar 4. Jawaban Siswa

Jawaban salah seperti yang ditunjukkan pada Gambar 4 dapat diartikan jika bilangan oksidasi suatu unsur telah mencapai keadaan maksimum maka masih 
dapat teroksidasi. Berikut adalah kutipan wawancara yang dilakukan, untuk memperjelas jawaban siswa tersebut:

Hasil wawancara menunjukkan bahwa kesulitan siswa dalam menentukan spesi yang akan teroksidasi pada larutan $\mathrm{KNO}_{3}$. Hal ini dikarenakan siswa belum mengetahui dengan baik konsep bilangan oksidasi, yang menyebabkan siswa mengalami kesulitan dalam memahami konsep sel elektrolisis pada larutan jika anion berupa ion sisa asam oksi.

\section{Kesulitan Menentukan Reaksi Sel Elektrolisis Larutan Di Anoda dengan Elektroda Tidak Inert}

Kesulitan dalam menentukan reaksi sel elektrolisis pada larutan yang terjadi di katoda ditelusuri dengan menggunakan instrumen TPKSE yang terdiri dari satu butir soal, yakni pada soal nomor 8. Melalui tes yang telah dilakukan diperoleh rerata jumlah siswa yang mengalami kesulitan sebesar 68,3\% dengan kategori jawaban SS, BS, SB dan TM. Pola distribusi jawaban-alasan siswa pada butir soal nomor 8 tersebut disajikan pada Tabel 7 .

Tabel 7. Pola Distribusi Pasangan Jawaban-Alasan Pada Butir Soal Nomor 8

\begin{tabular}{|c|c|c|c|}
\hline No & $\begin{array}{l}\text { Pilihan } \\
\text { Jawaban }\end{array}$ & $\begin{array}{l}\text { Jumlah } \\
\text { Siswa }\end{array}$ & Pilihan Alasan \\
\hline \multirow[t]{5}{*}{8} & A & 30 & $\begin{array}{l}\text { 1. } \mathrm{X} \text { adalah anoda jika anionnya berupa sisa asam } \\
\text { oksi } \mathrm{SO}_{4}{ }^{2-} \text { maka yang teroksidasi adalah air. }\end{array}$ \\
\hline & B & 28 & $\begin{array}{l}\text { 3. } \mathrm{X} \text { adalah anoda dengan elektrode tak inert maka } \\
\text { yang teroksidasi adalah logam } \mathrm{Cu}^{*}\end{array}$ \\
\hline & $C^{*}$ & $84 *$ & $\begin{array}{l}\text { 3. } \mathrm{X} \text { adalah anoda dengan elektrode tak inert maka } \\
\text { yang teroksidasi adalah logam } \mathrm{Cu}^{*}\end{array}$ \\
\hline & D & 2 & $\begin{array}{l}\text { 3. } \mathrm{X} \text { adalah anoda dengan elektrode tak inert } \\
\text { maka yang teroksidasi adalah logam } \mathrm{Cu}^{*}\end{array}$ \\
\hline & $\mathrm{E}$ & 1 & $\begin{array}{l}\text { 5. Pada larutan } \mathrm{CuSO}_{4} \text { terjadi reaksi reduksi } \\
\text { kation dan oksidasi anion pada elektroda X }\end{array}$ \\
\hline
\end{tabular}

Butir soal 8 digunakan untuk menelusuri kesulitan siswa dalam menentukan reaksi elektrolisis larutan pada anoda dengan elektroda tak inert. Jawaban yang benar untuk butir soal nomor 8 persamaan reaksi yang terjadi pada elektroda $\mathrm{X}$ adalah $\mathrm{Cu}_{(\mathrm{s})} \rightarrow \mathrm{Cu}^{2+}{ }_{(\mathrm{aq})}+2 \mathrm{e}^{-}($Opsi C) dengan alasan $\mathrm{X}$ adalah anoda dengan elektrode tak inert maka yang teroksidasi adalah logam $\mathrm{Cu}$ (Opsi 3). Siswa yang menjawab benar pada soal ini sebanyak 84 siswa, sedangkan 181 siswa menjawab salah. Jawaban salah dominan siswa yakni menjawab bahwa yang akan teroksidasi pada anoda adalah air (Opsi A) dengan alasan anionnya berupa sisa asam oksi $\mathrm{SO}_{4}{ }^{2-}$ (Opsi 1).Jawaban siswa tersebut ditunjukkan pada Gambar 5.

Jawaban salah seperti yang disajikan pada Gambar 5 tersebut dapat diartikan bahwa siswa belum memahami secara benar untuk menentukan reaksi oksidasi dengan elektroda tidak inert, siswa menganggap bahwa reaksi oksidasi pada anoda hanya bergantung pada anion tanpa melihat elektroda. Berikut adalah kutipan wawancara yang dilakukan, untuk memperjelas kesulitan yang dialami siswa tersebut.

Hasil wawancara menunjukkan bahwa kesulitan yang dialami siswa yakni menganggap reaksi oksidasi tidak bergantung dengan elektroda yang digunakan, 
pada butir soal nomor 8 elektroda yang digunakan yakni elektroda tidak inert yang berarti ikut bereaksi dalam sel elektrolisis tersebut, sehingga yang akan teroksidasi adalah logam $\mathrm{Cu}$ tersebut.

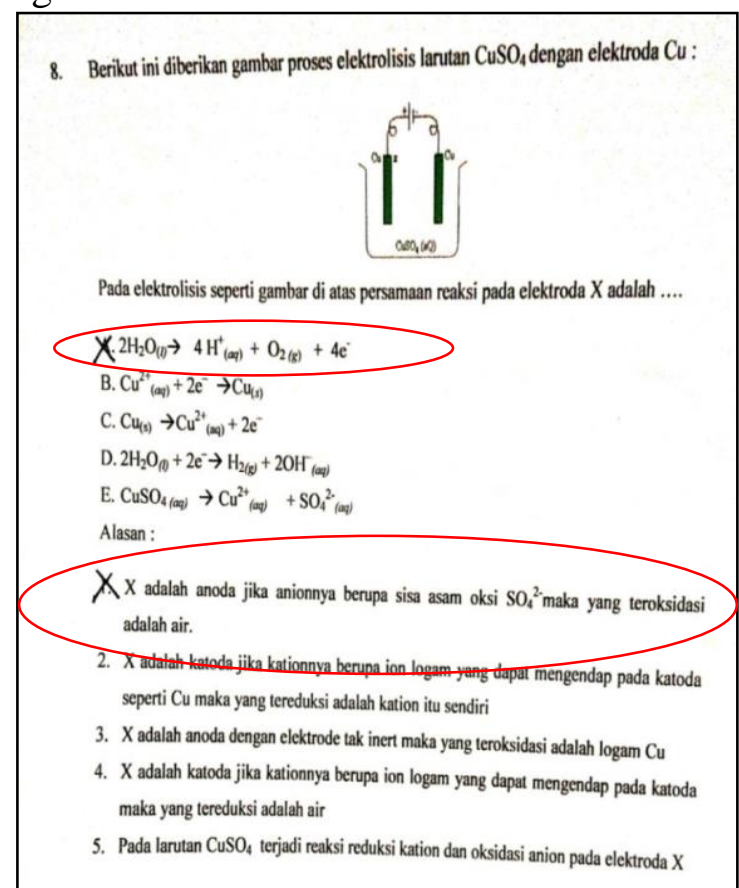

Gambar 5. Jawaban Siswa

\section{Kesulitan Siswa Menentukan Hasil Reaksi Total Sel Elektrolisis}

Kesulitan dalam menentukan reaksi sel elektrolisis pada larutan yang terjadi di katoda ditelusuri dengan menggunakan instrumen TPKSE yang terdiri dari tiga butir soal, yakni pada soal nomor 9, 10 dan 11. Melalui tes yang telah dilakukan diperoleh rerata jumlah siswa yang mengalami kesulitan sebesar 70,1\% dengan kategori jawaban SS, BS, SB dan TM. Berdasarkan jawaban salah dominan siswa dan wawancara yang telah dilakukan menunjukkan kesulitan dalam menentukan reaksi reduksi dan oksidasi. Hal ini dikarenakan siswa belum memahami secara baik konsep ciri dari terjadinya reaksi reduksi maupun oksidasi dan menuliskan setengah reaksi reduksi maupun oksidasi tersebut.

\section{Kesulitan Siswa Menenerapkan Konsep Hukum Faraday I Pada Perhitungan Sel Elektrolisis}

Kesulitan dalam menentukan reaksi sel elektrolisis pada larutan yang terjadi di katoda ditelusuri dengan menggunakan instrumen TPKSE yang terdiri dari satu butir soal, yakni pada soal nomor 12. Melalui tes yang telah dilakukan diperoleh rerata jumlah siswa yang mengalami kesulitan sebesar $71 \%$ dengan kategori jawaban SS, BS, SB dan TM. Berdasarkan jawaban salah dominan dan wawancara yang telah dilakukan menunjukkan kesulitan siswa adalah dalam menentukan bilangan oksidasi yang menyebabkan salah dalam perhitungan massa ekuivalen. Hal ini dikarenakan siswa belum memahami dengan baik konsep reaksi reduksi oksidasi sehingga tidak dapat menuliskan setengah reaksi reduksi yang digunakan dalam penentuan bilangan oksidasi, siswa menganggap bahwa bilangan oksidasi didapatkan dari jumlah atom unsur tersebut. 


\section{Kesulitan Menerapkan Konsep Hukum Faraday II Pada Perhitungan Sel Elektrolisis}

Kesulitan dalam menentukan reaksi sel elektrolisis pada larutan yang terjadi di katoda ditelusuri dengan menggunakan instrumen TPKSE yang terdiri dari satu butir soal, yakni pada soal nomor 13. Melalui tes yang telah dilakukan diperoleh rerata jumlah siswa yang mengalami kesulitan sebesar 71,1\% dengan kategori jawaban SS, BS, SB dan TM. Berdasarkan jawaban salah dominan dan wawancara yang telah dilakukan menunjukkan kesulitan yang dialami siswa adalah dalam menentukan massa ekuivalen pada kedua endapan. Hal ini dikarenakan siswa belum memahami dengan baik konsep reaksi reduksi oksidasi sehingga tidak dapat menuliskan setengah reaksi reduksi yang digunakan dalam penentuan bilangan oksidasi, siswa menganggap bahwa bilangan oksidasi didapatkan dari koefisien zat tersebut.

\section{SIMPULAN}

Berdasarkan hasil analisis data dan pembahasan, maka dapat disimpulkan Kesulitan yang dilakukan siswa pada masing-masing konsep adalah sebagai berikut: reaksi reduksi maupun oksidasi pada senyawa lelehan bergantung dengan jenis kation dan anion sama seperti dengan reaksi elektrolisis larutan, karena baik lelehan maupun larutan mengandung pelarut air. Ciri reaksi reduksi terjadi penurunan bilangan oksidasi, Katoda pada sel elektrolisis merupakan kutub negatif sehingga yang akan bereaksi adalah anion, semakin negatif potensial reduksi suatu zat maka akan semakin mudah tereduksi sedangkan semakin positif potensial reduksi suatu zat maka semakin sulit tereduksi. Dari hasil penelitian, beberapa saran yang dapat diajukan adalah pada pembelajaran kimia, khususnya konsep sel elektrolisis, agar lebih menekankan pada pemahaman konseptual siswa. Perlunya metode pengajaran yang tepat dan efisien untuk membuat siswa tertarik dengan kimia dan memahami konsep dengan baik, seperti pembelajaran dengan bantuan LKS sebagai bantuan siswa yang mengalami kesulitan dengan kategori tinggi.

\section{DAFTAR PUSTAKA}

Arifin, M. (1995). Pengembangan Program Pengajaran Bidang Studi Kimia. Surabaya: Airlangga University Press.

Arifin, Z. (2009). Evaluasi Pembelajaran, Prinsip-Teknik-Prosedur. Bandung : PT. Remaja Rosdakarya

Chang, R. (2010). Kimia Dasar : Konsep-Konsep Inti Jilid 2. Jakarta: Erlangga. Dahar, W. R. (2006). Teori-Teori Belajar \& Pembelajaran. Bandung: Erlangga. Depdiknas. (2003). Kamus Besar Bahasa Indonesia. Jakarta : Balai Pustaka.

Lumban Tobing, F. M., Sidauruk, S., \& Meiliawati, R. (2019). Kesulitan Memahami Konsep Kimia Unsur Golongan VII A (Halogen) Pada Mahasiswa Program Studi Pendidikan Kimia Universitas Palangka Raya Tahun Akademik 2018/2019. Jurnal Ilmiah Kanderang Tingang, 10(1), 72-80.

Fathurahman, H. P. (2011). Metode Penelitian Pendidikan. bandung: Pustaka Setia.

Harnanto, A. (2009). Kimia untuk SMA/MA kelas XII. Jakarta : Pusat Perbukuan. 
Sibarani, M., Sidauruk, S., \& Mulawi. (2019). Kesulitan Siswa Kelas XI IPA SMA Negeri Palangka Raya Tahun Ajaran 2018/2019 Dalam Memahami Konsep Pengaruh Penambahan Ion Senama Terhadap Kelarutan. Jurnal Ilmiah Kanderang Tingang, 10(2), 201-214.

Rahayu, S. (2016). Representasi makroskopik, submikroskopik, dan simbolik siswa kelas XII di sebuah SMA Negeri Kota Malang Terhadap Sistem dan Prinsip Kerja Sel Elektrokimia. Diunduh pada tanggal 15 November 2018 darihttp://jurnalonline.um.ac.id/data/artikel/artikelD874C97FB36E5F940575B92A5CEBE FD9.pdf

Sa'idah, A. N. (2017). Identifikasi Kesulitan Belajar Kimia Peserta Didik SMA/MA Menggunakan Two-Tier Multiple Choice Diagnostic Test Dalam Memahami Konsep Elektrokimia. Skripsi sarjana, tidak diterbitkan, Universitas Islam Negeri Sunan Kalijaga Yogyakarta. Diunduh pada tanggal 19 November 2018 dari http://digilib.uinsuka.ac.id/28164/1/13670047_BAB-I_IV-atau-V DAFTARPUSTAKA.pdf

Sidauruk, S., Abudarin, \& Hayati, S. (2018). Kesulitan Siswa Memahami Pereaksi Pembatas Di SMA Kabupaten Barito Utara Dan Kota Palangka Raya Tahun Pelajaran 2015/ 2016. Jurnal Ilmiah Kanderang Tingang, 9(2), 114132.

Sidauruk, S. (1995). Kesulitan Siswa SMA Memahami Konsep-Konsep Ilmu Kimia. Tesis Magister, tidak diterbitkan, IKIP Jakarta.

Sudjana, N. (1989). Dasar-Dasar Proses Belajar Mengajar. Bandung: Sinarbaru.

Sudjana, N. (2009). Penilaian Hasil Proses Belajar Mengajar. Bandung: PT. Remaja Rosdakarya

Suwarto. (2013). Pengembangan Tes Diagnostik dalam Pembelajaran. Yogyakarta: Pustaka Pelajar.

Suyono \& Hariyanto. (2011). Belajar dan Pembelajaran Teori dan Konsep Dasar. Surabaya: PT Remaja Rosdakarya.

Suryanto, E. 2018. Kimia Kelas X C1 Seri Hots Kurikulum 2013 Edisi Revisi. Surakarta : Mediatama

Thoha, M. (1990). Organisasi Konsep Dasar Dan Aplikasinya. Jakarta: CV. Rajawali.

Tim Penyusun. (2014). Pedoman Penulisan Karya Ilmiah (Skripsi dan Hasil Penelitian). Palangka Raya : FKIP UPR

Tresnasih, N. (2013). Analisis Konsepsi Mahasiswa Terhadap Materi Elektrolisis Menggunakan Istrumen Tes Three Tier Multiple Choice. Diunduh pada $\begin{array}{llll}\text { tanggal } & 19 & \text { November } & 2018\end{array}$ https://faridach.files.wordpress.com/2017/10/nia-tresnasih.pdf

Pramono, S. (2014). Panduan Evaluasi Kegiatan Belajar Mengajar. Jogjakarta: DIVA Press.

Yusuf, A. M. (2015). Asesmen dan Evaluasi Pendidikan. Padang: Kencana. 